\title{
К 80-ЛЕТИЮ СО ДНЯ РОЖДЕНИЯ ЮРИЯ СЕМЁНОВИЧА ОВОДОВА
}

\section{(28.08.1937 - 06.03.2014)}

В этом году исполняется 80 лет со дня рождения выдающегося ученого и организатора науки, доктора химических наук, профессора, действительного члена Российской академии наук Юрия Семёновича Оводова. Ю.С. Оводов внес значительный вклад в становление и развитие химии природных соединений, биоорганической химии, иммунохимии и иммунобиологии и широко известен как основоположник новых направлений и методов структурной химии и иммунохимии физиологически активных углеводсодержащих биополимеров.

Юрий Семенович родился 28 августа 1937 года в Харькове. В 1959 г. окончил химический факультет Московского государственного университета им. М.В. Ломоносова и начал работать в Новосибирском Институте органической химии СО АН СССР. В 1960-1962 гг. он прошел стажировку в Институте химии природных соединения АН СССР (г. Москва).

В 1962 г. Юрий Семенович был направлен в г. Владивосток, где он внес основополагающий вклад в организацию и становление Тихоокеанского института биоорга-

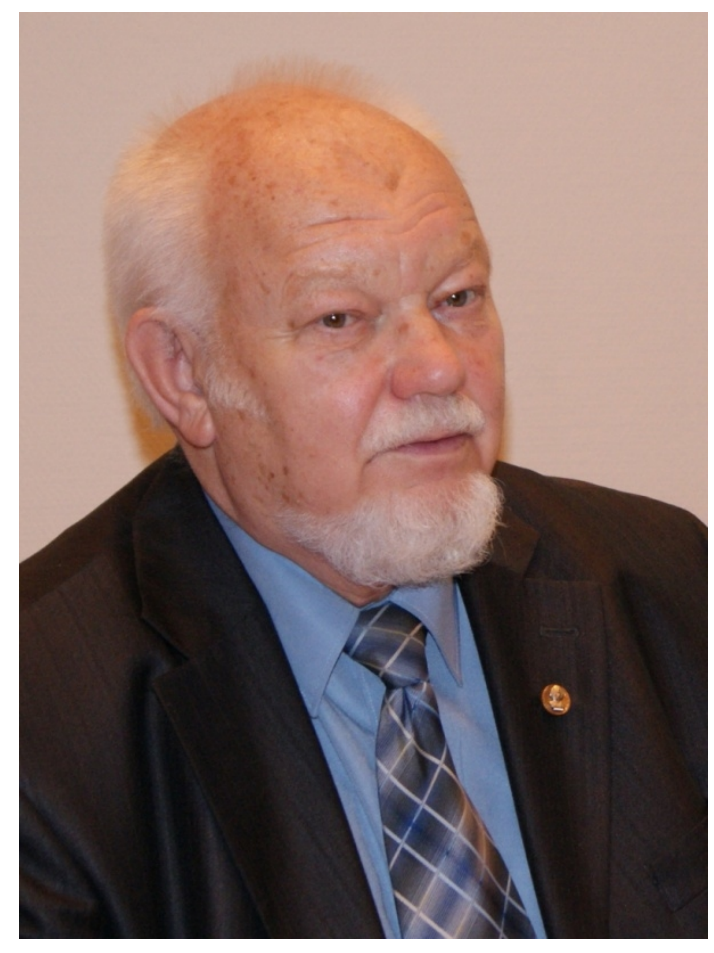
нической химии ДВО РАН. В 1963 г. Ю.С. Оводов успешно защитил кандидатскую диссертацию на тему «Строение гипсозида - тритерпенового олигозида из качима тихоокеанского» (научный руководитель академик Н.К. Кочетков).

Диссертацию на степень доктора химических наук на тему «Химическое исследование гликуроногликанов - кислых растительных полисахаридов» Ю.С. Оводов защитил в 1971 г., а в 1973 г. получил звание профессора по специальности «Биоорганическая химия».

В Тихоокеанском институте биоорганической химии ДВО РАН с 1964 по 1994 г. Юрий Семенович в течение ряда лет возглавлял лабораторию химии углеводов, а затем и отдел молекулярной иммунологии. В течение 20 лет являлся заместителем директора института по научной работе (1967-1987).

В 1990 г. он избран членом-корреспондентом АН СССР, а в 1992 г. - действительным членом Российской академии наук.

В 1994 г. он был приглашен в Институт физиологии Коми научного центра Уральского отделения РАН (г. Сыктывкар), где по его инициативе был организован Отдел молекулярной иммунологии и биотехнологии, которым он руководил до 2004 г. В эти же годы Ю.С. Оводов - научный консультант и главный научный сотрудник Института химии Коми НЦ УрО РАН, профессор Сыктывкарского госуниверситета, директор Учебно-научного центра «Физико-химическая биология» при СГУ и Сыктывкарском лесном институте.

В 2004 г. Юрий Семенович был избран на должность директора Института физиологии Коми НЦ УрО РАН, которым руководил до своей кончины. 
Ю.С. Оводовым впервые изучено химическое строение полисахаридов из морских растений и установлена их иммуномодуляторная активность. Определены структурные и иммунохимические свойства лектинов ряда морских беспозвоночных. При изучении строения онкофетальных антигенов выявлены закономерности в проявлении ими иммунологических свойств, открыт новый класс иммуноактивных биополимеров - онкопреципитины, позволяющие надежно выявлять раковые антигены и нормализующие опухолевые клетки. Выполнены исследования, посвященные выяснению структуры и физиологической активности антигенов грамотрицательных бактерий, которые привели к открытию новой группы иммунодоминантных сахаров. Определено химическое строение и физико-химические свойства полисахаридов ряда растений Республики Коми и других районов Европейского Севера России. Показано, что они обладают широким спектром физиологического действия. Разработаны биотехнологические способы получения пектиновых полисахаридов с помощью каллусных культур.

С 1995 г. по 2005 г. академик Ю.С. Оводов возглавлял Всероссийский научный совет по химии и технологии переработки возобновляемого растительного сырья при Президиуме РАН.

Юрий Семенович - автор около 500 научных работ, в том числе трех монографий, двух учебных пособий и более 30 патентов и авторских свидетельств. Он удостоен знака «Изобретатель СССР».

Академик Ю.С. Оводов был талантливым педагогом. Много лет он готовил студентов Дальневосточного и Сыктывкарского университетов в области биоорганической химии и молекулярной иммунологии. С 1999 г. возглавлял Учебно-научный центр «Физико-химическая биология» в Сыктывкаре, а с 2010 г. - магистратуру при Вятском и Сыктывкарском госуниверситетах. Он подготовил 11 докторов и 41 кандидата наук. Он является основателем научных школ по биоорганической химии и молекулярной иммунологии в ДВО РАН и физико-химической биологии в Коми НЦ УрО РАН.

Практически с первых лет организации научного журнала «Химия растительного сырья» Юрий Семенович Оводов принимал активное участие в работе редакционного Совета и оказал значительное влияние на его развитие.

За заслуги в научной, организаторской и педагогической деятельности Ю.С. Оводов награжден орденами Октябрьской Революции, Трудового Красного Знамени, «За заслуги перед Отечеством» IV степени и рядом медалей. Юрий Семенович - лауреат премии Ленинского комсомола (1972 г.), премии РАН им. И.И. Мечникова (1993 г.), премии РАН Ю.А. Овчинникова (2003 г.) и премии Правительства Республики Коми (2011 г.).

Научным фондом им. А.М. Бутлерова при жизни Юрия Семеновича и с его согласия учреждена Научная премия им. академика Ю.С. Оводова, состоящая из одноименной медали, сертификата и денежного вознаграждения. Научной премией им. академика Ю.С. Оводова награждаются номинанты за достижения в области химии, биохимии и иммунохимии углеводов, а также в смежных с ними областях знания.

Ю.С. Оводов похоронен на Краснозатонском кладбище в Сыктывкаре.

Юрий Семёнович был ярким и привлекательным человеком. Для него были характерны отеческая забота об учениках, душевная доброта и научная щедрость. Любил он в разговорах, выступлениях и докладах применять образные и яркие суждения. Я посчитала, что хорошей памятью академику Юрию Семеновичу Оводову будет их опубликование в журнале «Химия растительного сырья», в редколлегии которого он активно работал. В предлагаемую вниманию читателей подборку включены высказывания и размышления Ю.С. Оводова, которые извлечены из записей, сделанных мною на коллоквиумах Отдела молекулярной иммунологии и биотехнологии и заседаниях ученого совета Института физиологии Коми НЦ УрО РАН, возглавляемых Ю.С. Оводовым с 1994 г. до его кончины (6 марта 2014 г.).

Валентина Ивановна Прошева, ведущий научный сотрудник отдела молекулярной иммунологии и биотехнологии Института физиологии Коми НЦ УрО РАН, доктор биологических наук, e-mail:V.Prosheva@physiol.komisc.ru; val-prosheva@yandex.ru 
Главное, чтобы человек был хорочим.

Без даты

Хорошего химика можно определить по тому, умеет он готовить борщ или нет.

Без даты

Молодым надо думать, как выживать, как использовать интеллектуальную собственность для зарабатывания денег.

2002

Талант без денег - сейчас пустое.

2002

Организационная работа - это очень трудно.

2002

Руководитель аспирантов должен нести за них ответственность. 2009

Средняя продолжительность жизни академиков РАН - 80 лет, но академики хотят жить 100 лет. 2010

Никогда не встречал более талантливого человека, чем Мстислав Всеволодович Келдыш. 2011

Нобелевские лауреаты - все молодые. Надежда на молодых: не только стоять у станка, но и шевелить мозгами.

2011

Молодежь становится старой. Идет смена поколений. Наш возраст уходит. 2011

Готовят зомби, рабов, рушат образование.

2011

Есть статья - есть работа, нет статьи - нет работы.

2012

Плохо, когда, не задумываясь, выполняется экспериментальная работа (пусть думает шеф). 2012

Ученый - это мыслитель, он создает что-то новое.

2012

Если мозги не упражнять - мозги жиреют, возникает болезнь Альцฺгеймера.

2012

Главное - идея. Она движет.

2012

Для большинства молодежи нет смысла жизни, а только удовольствие, секс, где не надо мозгов. 2012

Год хороший, не високосный. Умирать не будем.

2013

Идут нападки на Академию.

27.02.2013

Пусть доктора наук не просто сидят, а думают головой.

2013

Жаль, что сейчас в науку идут не самые лучшие, но можно выбрать.

2013

Пусть меньие статей, но выше качество.

2013

Ю.С. Оводов 
